Article

\title{
"Divided by a Common Language": The Use of Verbatim in Carol Ann Duffy and Rufus Norris' My Country; A Work in Progress
}

\author{
Shauna O'Brien \\ Department of Foreign Languages, Faculty of Education, Palacký University, 77147 Olomouc, Czech Republic; \\ obriens5@tcd.ie \\ Received: 22 November 2018; Accepted: 20 March 2019; Published: 22 March 2019 \\ check for \\ updates
}

\begin{abstract}
My Country; A Work in Progress' written and arranged by the poet Carol Ann Duffy is a verbatim play that uses interviews conducted with people from various regions in England, Wales, Scotland, and Northern Ireland to explore the causes of the EU referendum result. With the recent rise of populism across Europe, Britain, and America, an increased scepticism of established news media organisations, and a widespread disillusionment with the so-called political elite class, verbatim theatre's "claim to veracity" and use of real-life testimonies seems to provide an attractive forum for both playwrights and audiences to investigate the underlying causes prompting these political and social movements. This paper examines how Duffy's highly-fragmented arrangement of My Country's verbatim voices in tandem with their re-citation and reterritorialization in the bodies of the performers on the stage ironically undermines the "claim to veracity" that its verbatim approach implies.
\end{abstract}

Keywords: verbatim theatre; brexit; contemporary British society; British theatre

The strength of verbatim theatre is that it's absolutely truthful, it's exactly what someone said.

Nicholas Kent. (Hammond and Steward 2008, p. 152)

Speaking frightens me because, by never saying enough, I also say too much.

Jacques Derrida. (Derrida 2005, p. 9)

\section{Introduction}

Verbatim theatre is a specific type of documentary theatre that uses recordings or transcripts of interviews conducted outside a theatrical context as the raw material for a dramatic performance. With the recent rise of populism across Europe, the United Kingdom, and the United States of America, an increased scepticism of established news media organisations, and a widespread disillusionment with the so-called political elite class, verbatim theatre's apparently unmediated (or at least, less mediated) access to real life testimonies provides an attractive forum for both playwrights and audiences to investigate the underlying causes prompting these social and political movements. While Will Hammond acknowledges that "no play, like no newspaper article, is without bias and inflection", he also claims that verbatim theatre's use of voices originating in real life can, nevertheless, "provide what journalism fails to provide, and at a time when it is sorely needed" (Hammond and Steward 2008, p. 11). Indeed, the genre's recent resurgence suggests its growing appeal as an aesthetic tool for playwrights to interrogate an increasingly fractured modern world. Subjects that have been staged using the verbatim technique include the Palestinian-Israeli conflict (Alan Rickman and Katharine Viner's My Name is Rachel Corrie), the Ipswich Murders (Alecky Blythe's London Road), privatization in Britain (David Hare's The Permanent Way), terrorism (Robin Soans' Talking to Terrorists), and institutionalised racism (Richard Norton-Taylor's Colour of Justice). Perhaps it 
is unsurprising, therefore, that verbatim was employed by Britain's National Theatre (NT) to address one of the most controversial and divisive issues of recent years-the EU Referendum.

Within days of Britain voting to leave the EU, the NT had dispatched a team to various regions of the UK to conduct interviews with members of the British public on the subject of the referendum. ${ }^{1}$ The testimonies derived from these interviews formed the raw material for one of the earliest theatrical responses to Brexit, My Country; A Work in Progress, a verbatim play formed from "the words of people across the UK" (Duffy and Norris 2017). Directed by Rufus Norris, Artistic Director of the NT, the play was first performed on the Dorfman stage of the NT in London less than nine months after the EU Referendum, before touring throughout the UK. ${ }^{2}$ The verbatim material was compiled and arranged by Norris and British poet laureate Carol Ann Duffy with additional text written by Duffy, and uses the allegorical conceit of a meeting between personifications of the UK's regions (East Midlands, Northern Ireland, the North-East, the South-West, Caledonia, and Cymru) as a theatrical framework to present the verbatim voices of the play's interviewees.

The play depicts the female personification of the UK, Britannia, as she convenes and chairs this meeting within a setting that resembles a community centre repurposed as a polling station. The regional personifications, who give voice to their constituents via the verbatim material, are all costumed in the semi-formal attire of civic councillors. In addition to presiding over the regional voices, the character of Britannia also acts a conduit for the most prominent political figures who emerged during and after the EU Referendum campaigns (David Cameron, Boris Johnson, Nigel Farage, Michael Gove, and Theresa May). These political voices thread a timeline through the tapestry of regional verbatim voices, beginning with Cameron's formal announcement of the referendum in 2013 to his resignation after the referendum result, and Theresa May's ascendancy to leader of the Conservative Party and Brexit Prime Minister. In addition to this chronological framework, the play is divided thematically into 12 sections, along subjects such as the European Union, Hardship, Immigration, and Political Leadership, to which the verbatim voices (via their regional conduits) respond.

This article will examine the reasons why Norris and the NT considered the verbatim technique as the most appropriate method to interrogate the divisions that emerged during and after the EU Referendum campaign and the socioeconomic issues that prompted what was for many such an unexpected result. According to Hammond, verbatim theatre asserts a "claim to veracity" that prompts audiences to approach a play "not just as a play but also an accurate source of information" (Hammond and Steward 2008, p. 10). The verbatim technique's frequent use to explore controversial issues on-stage, such as tribunals, perversions of justice, and marginalised voices testifies to its appeal for theatremakers as an effective conduit for real life events and experiences. Therefore, while the verbatim technique was employed by the NT to achieve a more direct engagement with contemporary British society, the resulting play was also deployed as a platform for the voices of this British society and implicitly proffered as a contribution to the discourses of the British public sphere.

This article attempts to demonstrate, however, how Duffy's highly-fragmented arrangement of My Country's verbatim voices in tandem with their re-presentation by the performers on-stage ironically undermines this "claim to veracity" that its verbatim approach implies. In contrast to Nicholas Kent's assertion above, My Country's formal approach arguably serves to accentuate the gulf between the "realness" of the verbatim voices and the "truths" they claim to convey. This article argues that My Country can be more productively read as a reflection of the divisive and cacophonous debate that occurred during and after the EU Referendum rather than a remedy to this cacophony as its theatremakers envisaged. Indeed, My Country arguably reveals a novel approach for subverting the verbatim form's "claim to veracity", not by criticising the mediation of "real" voices on-stage but by interrogating the veracity presumed to lie behind the mediation of these "real" voices.

1 For more information on the production see: "My Country; A Work in Progress", The National Theatre (website), https: / / www.nationaltheatre.org.uk/shows/my-country (The National Theatre 2018b).

2 The author was kindly allowed to view a recording of the performance at the (National Theatre Archives 2017). 


\section{Background}

In the wake of the Brexit vote, the UK appeared to be a nation split asunder. While $52 \%$ of the voting population celebrated their victory, the $48 \%$ who had voted to remain in the European Union expressed complete shock at the unexpectedness of their loss. For many proponents of Brexit, their opponents' shock became a palpable signifier of their alienation from the experiences of voters living outside the more affluent metropolitan centres of the UK. Sunday Times' political editor Tim Shipman identified the result as a "victory for outsiders over insiders", of the "provincial classes" over the metropolitan elites and political establishment (Shipman 2016, p. 583). For many, the Arts and Cultures sector represented the worst (and most visible) excesses of this elite class of "insiders", particularly in light of the strident support for remaining in the EU expressed by many of its practitioners. Only a month before the referendum took place, the Creative Industries Federation released a poll that "showed more than 96\% support for Remain" among its members. ${ }^{3}$ The Chief Executive of the Federation, John Kampfner, claimed that the result of the poll projected "a clear signal about the importance of EU membership for the continued success of the UK's fastest growing sector" (Stewart and Brown 2016).

The same day as these findings were released, an open letter staunchly endorsing the Remain campaign was also published, signed by such well-known luminaries of the UK's Arts and Cultures industries as Benedict Cumberbatch, Keira Knightley, Dame Kristin Scott-Thomas, Dame Vivienne Westwood, and Dame Carol Ann Duffy. "Let's not become an outsider shouting from the wings", the letter beseeched readers, arguably consolidating the position of its signatories as the very "insiders" against whom the Leave voters were revolting, celebrities advocating policies to those at the sharp end of these policies' consequences. While the letter argued that "[l]eaving Europe would be a leap into the unknown for millions of people across the UK who work in the creative industries, and for the millions more at home and abroad who benefit from the growth and vibrancy of Britain's cultural sector", many Leave voters considered themselves excluded from the group of people who could benefit from this "growth and vibrancy". ${ }^{4}$ The shock expressed by many practitioners from this sector became further evidence that they were simply out-of-touch and not serving the $52 \%$ of British voters who had decided to leave the EU. During a BBC radio debate addressing the impact of Brexit on the UK's future cultural activity, this correlation was drawn by Norris, who observed that there was "no question" that the arts community had been "surprised" by the result and had "to reflect that [it was] slightly out-of-touch with the way that most of the country is feeling" (Stewart 2016). As Artistic Director of Britain's national theatre, Norris regarded this oversight as particularly egregious and imperative to remedy. For Norris, the way to achieve this engagement was "very simple". The artistic community "just had to listen" (Elmes 2017).

The verbatim technique, therefore, seemed to provide the NT with a means to achieve this goal by offering the theatre direct access to voices outside these urban centres and in particular to those of Leave voters, not typically considered among the NT's audience or practitioner demographic. As Alison Forsyth and Chris Megson observe, documentary theatre (such as verbatim) has often been deployed for precisely this purpose, to "champion the hitherto suppressed stories of those excluded from mainstream theatre, by dint of class, gender, or ethnicity" (Megson and Forsythe 2009, p. 4). The NT's use of the verbatim technique to explore British identity and British values in post-Brexit UK, therefore, allowed the theatre to mitigate inevitable accusations of liberal bias (that a fictional rendering by a playwright might have incurred) in their representation of these British voices, particularly those

3 More information relating to this poll can be found at "Federation: EU Referendum Response", Creative Industries Federation. 8 June 2016. https: / / www.creativeindustriesfederation.com/news/federation-eu-referendum-response (Federation: EU Referendum Response 2016).

4 The entire open letter can be viewed at: "Hundreds of figures from Britain's creative industries call for UK to stay in the EU”, Britain Stronger in Europe. 20 May 2016. https:/ / www.strongerin.co.uk/hundreds_of_figures_from_britain_s_creative_ industries_call_for_uk_to_stay_in_the_eu\#EsfqoIC8Ax3v04FP.97 (Britain Stronger in Europe 2016). 
regional voices that had apparently been consigned to the margins of the majority of British theatres. Norris' goal of "trying to make the National Theatre's programme more resonant and talk to broader constituencies" $^{\prime \prime}$, therefore, at least partly prompted the verbatim technique to be adopted for this work.

By using "real voices" from across the UK, Norris and Duffy also sought to foster dialogue in the theatre by attempting to create a non-partisan forum within which the voices of British people on both sides of the referendum divide would share (what Norris referred to as) the "lived experiences" that had prompted them to vote Leave or Remain. As Norris explained, these "lived experiences" comprise "when people are talking from the heart but also a place of experience that [she or he] has lived" rather than "what they've read off Facebook, or The Daily Mail, or The Guardian", which according to Norris, is "not lived" and therefore should not be included (Sedgman and Reidy 2017). The play would "[use] theatre as a place of debate" and encourage audiences to "drop [their] self-righteousness and certainty" regarding the motivations of people whose voting preference had deviated from their own (McCorgray 2017). Indeed, Norris recalled the vitriol expressed by many of his colleagues working in the Arts towards those who had voted to leave the EU, and ascribed the strength of their antagonism to the estrangement of the artistic community to the realities of these voters' lives. By using "personal testimony" as the raw material for My Country, therefore, Norris hoped that these "real voices" could foster a degree of empathy between those on both sides of the referendum divide that a fictionalized drama could not. As Norris argued, "[w] hen people are talking from their own experience, it has a validity and is incredibly rich and suddenly you start listening in a way that is meaningful" (Sedgman and Reidy 2017). My Country's use of verbatim, therefore, was crucial for Norris in counteracting the vitriolic rhetoric that emerged during and after the referendum because it fundamentally altered how a play was received by audiences.

The importance of verbatim theatre's "claim to veracity" to My Country can be inferred from the playscript's repeated assertions of its origins in "real life". In the first section of the play (The Arrivals), its verbatim nature is explicitly invoked by the character of Britannia, who welcomes the audience to the performance by informing them that the actors on stage will be "speak[ing] verbatim in the voices of [their] regions" (Duffy and Norris 2017, p. 7). She underlines the "real" source of the voices again when she introduces the regional characters: "I move to the Opening Voices. Verbatim" (Duffy and Norris 2017, p. 11). The "real life" roots of the play's text are further emphasised by the actors on-stage when they introduce each interviewee's voice in the play by raising a large photograph of the interviewee and naming them. In the concluding moments of the play also, the original audio recording of the verbatim voices performed by the actors in one of the early scenes is played, thereby allowing the audience to appreciate the fidelity with which these voices are being conveyed by the performers. Finally, the play's verbatim status was given prominence in the paratexts of its production, its programme notes including labelled and numbered extracts from the interviews conducted by the NT (Theatre program for My Country; A Work in Progress). Indeed, the verbatim character of the play was reiterated by Norris, Duffy, and the actors in interviews, articles, and by critics reviewing the production as the most significant feature of the play.

As Janet Gibson observes "[v]erbatim theatre pieces are deliberately framed and marketed as verbatim" because this descriptor generally "functions as a signifier that the product is closer to 'the truth'". While Gibson rightly points out that "many audiences may be aware that their experience is a highly mediated one", she also notes that "this way of producing theatre is often a drawing card to them" because of the apparent proximity of the verbatim material to the truth (Gibson 2011, p. 12). Therefore, while audiences might be aware that the voices they are hearing on stage are being mediated by the theatremakers' re-presentations of this material, the verbatim form still privileges the spoken utterances that are presumed to lie behind this mediation as vehicles for the truth. This article will

5 Full interview can be found at: "My Country: 5 Minutes with National Theatre's Rufus Norris", Cambridge Arts Theatre (website), 19 May 2017. https:/ / www.cambridgeartstheatre.com/news/my-country-5-minutes-national-theatres-rufusnorris (Cambridge Arts Theatre 2017). 
argue, however, that My Country ironically performs a destabilisation of its own verbatim material's truth-claim. ${ }^{6}$ Although Norris' adoption of the verbatim technique for My Country was motivated largely by the form's "claim to veracity", this article will attempt to demonstrate how Duffy's treatment of the real spoken utterances in My Country actually forces the audience to examine the verbatim material itself, not so much to interrogate its mediation by the theatremakers but rather the truth that is presumed to lie behind this mediation.

\section{Process of Developing My Country; A Work in Progress}

Prior to Duffy's involvement in the process of My Country's development, the verbatim material gathered by the NT had already been subject to extensive curation by Norris and the NT's team of interviewers. This intervention occurred at the earliest stages of the process in the selection of individuals to be interviewed. Jez Casey (one of the NT interviewers) pointed out that they took pains to ensure that they achieved as much balance geographically (across the UK's various regions) and demographically (in terms of rural and urban locations and across different age groups) in these voices as possible. Casey recalls how the team initially "sat down with a map and lots of post-it notes" in order to achieve this desired "geographical spread" (Sedgman and Reidy 2017). In spite of this effort, however, London was completely excluded from this selection. Indeed, the only "representatives" of the London region in the play are the political voices of Westminster, a choice that arguably strengthens the very dichotomisation of metropolitan elites and regional constituents that the play seeks to remedy.

Furthermore, Norris admitted that after these interviews had been collected and transcribed, it was decided that approximately $5-10 \%$ more Leave voices would be presented on stage in the final edit of the play than Remain voices, exceeding even the margin represented by the referendum vote. Norris reasoned that it was "a fairly safe assumption to say that [there would be] a balance leaning towards Remain in [the NT's] audiences", and that these additional Leave voices would, therefore, provide a counterbalance to this audience make-up and "encourage the audience to listen" (Sedgman and Reidy 2017). Consequently, before the verbatim material had been received by Duffy, the theatre-makers involved in the production had already determined whose voices would be heard and whose would be excluded.

In most verbatim plays, it would be unfeasible for a theatre company to attempt to stage all the verbatim material compiled and the inclusion of what can often amount to massive amounts of transcribed material would confront theatremakers and audiences with perhaps an unmanageable burden. Theatre practitioners are undoubtedly constrained by the logistics that are involved in producing and staging any play. As Stuart Young observes, "[i]t is not uncommon for productions and theatre-makers to advertise, almost as a badge of honour, that the material re-presented is but a small portion of what was recorded" (Young 2017, p. 28). Though not unproblematic, a certain amount of abbreviation is usually necessary to render the material stageable at all. However, the degree to which the testimonies of My Country were abbreviated raises certain questions regarding not only how the "words of people across the UK" were deployed by the theatremakers but how verbatim theatre's "claim to veracity" problematizes this deployment.

Even by the standards of the many diverse plays that comprise the canon of verbatim theatre, the processes of editing and re-arrangement exercised in the composition of My Country were relatively excessive. While at certain points in the play, interviewees' responses are as long as a paragraph

6 It must be recognised that this mediation of participants' voices in verbatim theatre has not avoided criticism. Stephen Bottoms, for example, has written on precisely this issue of the role of theatre practitioners in mediating their participants' voices. While criticising certain practitioners' approaches (e.g., David Hare and Robin Soans), however, Bottoms identifies Techtonic Theatre's The Laramie Project as an example of a verbatim play that productively employs a "textually reflexive documentary theatre", which allows theatremakers to "[remind] audiences that history itself is necessarily complex, uncertain, and always already theatricalized" (Bottoms 2006, pp. 64-67). Other works, such as Dennis Kelly's critique of the verbatim technique, Taking Care of Baby, explicitly criticise the mediation at work in verbatim theatre and the attempts of theatre practitioners to mitigate this mediation at all. 
(e.g., in the opening section, "The Arias" (Duffy and Norris 2017, pp. 11-15) and closing section, "The Leave-Taking" (Duffy and Norris 2017, pp. 55-58), at other points these responses are edited down to a single word (e.g., at several points in the "Listening and Leadership" section (Duffy and Norris 2017, pp. 31-39). Furthermore, these brief snippets of verbatim material are re-arranged and re-presented by Norris and Duffy as interjections in a debate between the regional personifications rather than in the context of the one-to-one interview of their original utterance. During the performance of the play, the actors direct their verbatim voices to one another or to the audience, and often these voices are spoken by the different actors simultaneously, creating the impression that they are impassioned responses in an argument between the various interviewees. The interviewer's presence, therefore, is eradicated from the play's verbatim materials in order to facilitate this recontextualisation. Although Young observes that the "interweave[ing] [of] various speakers and their testimony throughout a play" can be used productively by theatremakers to emphasise "differences as well as similarities [ ... ] between disparate characters' experiences and perspectives", he also points out that this re-arrangement can misleadingly "create the impression of an objective, polyvocal overview of a particular topic" that can foster "dubious assumptions about "truth". The radical decontextualisation of the verbatim material of My Country, therefore, prompts an examination of how the play's "seemingly transparent representation of testimony" was elicited (Young 2017, pp. 30-31).

Although the removal and transfer of verbatim or documentary material from the original context of its utterance to the space of the theatre ensures a certain degree of decontextualisation in all fact-based theatre, Janet Gibson warns that this transfer can lead practitioners into ethically dangerous territory. For Gibson, this danger is amplified when "the manipulations of the writers and the nature and transparency of the collaboration between, [and] the power relationships of, subjects and writers" are not made clear to the audience, as was certainly the case in My Country (Gibson 2011, p. 3). Unlike other verbatim plays, My Country gave no indication to audiences watching the performance of the play how the verbatim material was sourced, whether in response to a question, in agreement or disagreement with the interviewer, or as an impulsive response to a word or image.

Several members of the NT's team attempted to mitigate this absence of information about the interviewing process by discussing their own methods and approaches in gathering the verbatim material; how they attempted as far as possible to avoid posing leading questions to their interviewees or conveying emotions (e.g., approval or disapproval that could be interpreted by their subjects as encouragement or discouragement) in response to their answers. In spite of these concerns, however, the interviewers appear to have been free from any strict rubric for questioning their subjects. Therefore, while one of the interviewers, Sarah Blowers, recalled that she "found that showing no emotion or reactions to what was said" allowed her to "process information in a different way" and to absorb "lots of views", it is impossible to know how many other interviewers were as mindful as Blowers of their potential influence on their interviewees' responses. For another interviewer, Rhiannon White, this flexibility allowed her to provide a richer and more nuanced portrait of the interviewees. "[A] lot of my questions weren't really about politics", she recalled, "but about people's experiences". Nevertheless, White also admits that she used word-association to elicit responses from her interviewees, particularly "words that were in the press or that were being thrown around [during the referendum campaigns]" (Sedgman and Reidy 2017). Whether the interviewees' responses to these word-association exercises were included in the final edit of the playscript is unclear but this ambiguity itself exposes the problems of completely eliminating all references to the methods used to collect the play's verbatim material.

Indeed, the radical decontextualisation and re-arrangement of My Country's verbatim voices completely obfuscates the original circumstances within which these utterances were made, the interview situations that gave rise to their delivery, or their relationship to the semantic context within which they were originally uttered. As Ryan M. Claycomb points out, "this disruption of the monologic voice" of the interviewees that occurs in the construction of a verbatim playscript "inevitably means the playwright is vested with much of that authority, which plays out in the politically charged processes of editing and ordering of the final script" (Claycomb 2003, p. 102). For the theatremakers 
involved in the composition of My Country, however, the addition of this disruption to the lack of clarity surrounding the circumstances of the verbatim material's derivation could prompt audiences to question the accuracy of the interviewees' words or (and although there is no suggestion that this occurred) prompt accusations of their words being misleadingly edited to convey opinions they did not express.

In My Country, however, these "edited and ordered" words of the playscript were further alienated from the original contexts of their utterances in their deterritorialization in the bodies of the six performers. Obviously, the verbatim technique (as its name makes clear) necessitates this re-presentation and re-territorialisation of the play's voices, from original speaker to the performer. In My Country, however, this re-territorialisation is made conspicuous by each performer giving voice to up to nine interviewees, varying in age, gender, and physicality. The production's cast of three female and three male actors (Seema Bowri, Laura Elphinstone, Penny Layden, Stuart McQuarrie, Cavan Clarke, and Christian Patterson) not only imitate the various regional accents of the interviewees but also their tone of voice and vocal idiosyncrasies. As Cavan Clarke recalled, the actors "tried to honour every stutter and every cough" of the interviewees in the performance (Warwick Arts Centre 2017). The actors' body language is also individuated according to the interviewee they are portraying. Penny Layden, for example, mimics the stooped shoulders and shuffling gait of Boris Johnson. The actors also supplement the verbatim voices through gestures, shaking their heads with disapproval as they recall an experience or jabbing a finger aggressively towards the other actors as they argue their point.

Although the actors did not have access to video footage of the interviewees (excluding the politicians whose verbatim material was taken from well-documented speeches), this lack of visual material does not necessarily preclude an accurate portrayal of the interviewees' physical movements. Lib Taylor describes how for the verbatim practitioner Alecky Blythe, the recorded material itself "becomes a kind of score which determines not only how the characters speak and sound but how they move, stand or sit since, for example, the speed, energy and cadences of the dialogue and the hiatuses in the spoken text shape physical rhythms and patterns of movement" (Taylor 2013, p. 273). Nevertheless, like the re-arrangement of the verbatim voices by Norris and Duffy to create the dynamic of a heated debate between these voices, the physical gestures inferred by the actors from the voices were also largely directed towards constructing this same dynamic of a polyvocal debate. These gestures, therefore, would inevitably differ from those originally made by the interviewees in the context of their one-to-one interviews.

In fact, even the simple juxtaposition between the actor and the speaker adds a quality to the re-presentation of the interviewees' voices that was almost certainly absent from their original utterance. The re-voicing of 13-year old Curtis Thomas Popp's shy and tentative assertions of his hometown by the physically imposing actor Christian Patterson (who performs the role of Cymru) provoked laughter from the audiences in performance at the National Theatre, simply due to the incongruity of actor and speaker (Duffy and Norris 2017, p. 20). The laughter elicited from this re-presentation exposes how the verbatim material transforms as it passes through the hands of the theatremakers (from the interviewers to the performers on-stage), and how this material is remoulded and re-presented for an audience's consumption, presenting interviewees' words in ways that differ from their original utterance.

Furthermore, while each actor individuates these voices, the voices become more argumentative and overlap with one another as the play progresses making them difficult to distinguish and parse out by an audience. During these vocal melees on-stage, the audience is only really clearly able to identify from which regions these voices originate. Although this dramaturgical choice appears to have been employed to allow each region to act as a conduit for their constituents' voices, each voice's identification according to a particular geographical location implies a stasis and immobility that might be misleading to ascribe to these voices. In the context of a play that purports to represent the "real" voices of British people, this reterritorialization arguably reinscribes the very regional divisions and geographical boundaries that the play seeks to undermine. This dramaturgical choice is further problematized by the conformity of these regional characters to what Susannah Clapp referred 
to as "antic stereotypes" (Clapp 2017). In the scene entitled "The Feast", each region contributes their local cuisine to the celebration (e.g., Caledonia offers Talisker and haggis) and engages in a game of one-upmanship to lay claim to the most superior cultural heritage. Only moments after the Scottish poet Robert Burns has been pitted against Welsh poet Dylan Thomas, these boasts are rebutted by statistics that reveal each regions' less desirable claims to fame, such as being the "binge-drinking capital of the UK" (North), having the "highest rate of drug trafficking outside London" (Cymru), being voted the "third worst place to live in the UK" (Northern Ireland), having the "highest rate of teen pregnancies in the country" (East Midlands), or the "highest use of marijuana" (South) (Duffy and Norris 2017, pp. 39-46). While these regional attributes are presented playfully and with humour by the performers, the subordination of the individual voices of the interviewees to their stereotypical regional characters suggests an overriding commonality based solely on geographical location binding these disparate voices that might not in fact exist.

In a play attempting to undo simplistic notions of British identity and undermine the dichotomisation of Britain by the EU Referendum into Leavers and Remainers, this use of personified regional stereotypes to convey the voices of the various interviewees seems counterproductive. Judith Butler's observation that "speaking is itself a bodily act" (Butler 1997, p. 10), that "there is what is said, and then there is a kind of saying that the bodily 'instrument' of the utterance performs", seems particularly apt in this instance (Butler 1997, p. 11). Indeed, Duffy described how she envisaged the actors as different instruments performing the score of the playscript's verbatim voices. During one rehearsal, Duffy expressed this intention to the actors:

I thought of you all as instruments in an orchestra so that you play the voices of Wales and you play the voices of the south-west as though you were a violin or you were a harp or whatever. But you're also in an orchestra (Elmes 2017).

Therefore, although the selection and arrangement of the transcript material was the result of a collaborative effort between Norris and Duffy (as well as the actors in rehearsal), the score-like quality of the final version of the script can largely be attributed to Duffy's involvement. Norris recalled how Duffy expressed her intention to arrange the voices "in a way which [made] some kind of musical sense to the ear" and ascribed this approach to her background as a poet (The National Theatre 2018a). Perhaps a theatremaker coming from a different artistic background would have been less attuned to the materiality of the voices and more concerned with the content of the interviewees' conversations.

The sum of these excessive interventions by the theatremakers involved in the development of My Country serves to draw audiences' attention to the materiality of these spoken utterances (of the playscript as a score) that comprise the play's verbatim content and the malleability of this material. Duffy and Norris' exploitation of this malleability (via the radical decontextualisation, editing, re-arrangement, and reterritorialization of the interviewees' words) serves to undermine the value invested in these utterances as vehicles for the truth and indeed of these words as representative (or even at least, approximations) of the interviewees' intended meanings. The play's treatment of the verbatim material, therefore, highlights the absence of a determinate meaning that can be ascribed to the interviewees' words, at least beyond what the words' historicity has, in Butler's words, "come to constitute its contemporary meaning" through the "sedimentation of its usages" (Butler 1997, p. 36). At the same time, the play's repeated assertions that its verbatim material is based on "real" spoken utterances, highlights the volatility of this system of semio-linguistic exchange (of the interviewees' words for an approximation of their intended meaning) that defines verbatim theatre, a volatility made palpable when this material is subjected to such extensive manipulation by theatre-makers.

As Butler observes, "speech is always in some ways out of our control" (Butler 1997, p. 15). While this loss of control (what Butler refers to as the "limit of intentionality" (Butler 1997, p. 10) is an intrinsic and unavoidable feature of all speech, verbatim theatre's decontextualisation of speakers' utterances coupled with the authority inferred to these "moments of utterance" (Martin 2006, p. 14) intensifies this "linguistic vulnerability" (Butler 1997, p. 30). This is not to suggest that these "moments of utterance" are completely ineffectual or that the speaking subject lacks agency in their utterance 
but rather that these utterances do not wield the authority that their verbatim status suggests. As J.L. Austin observed, speech like all acts is "liable [ . . ] to be done under duress, or by accident, or owing to this or that variety of mistake, [ . . ] or other intentionality" (Austin 1975, p. 21). Although the opinions of My Country's interviewees' may not have been elicited "under duress", it is still inevitable that interviewees' may not say what they mean, may not mean what they say (intentionally or unintentionally), and the opinions that they do express may not be as fixed or unified as their preservation in the play's verbatim material implies.

The theatremakers of My Country draw attention to this linguistic vulnerability of the spoken utterance precisely by stretching the "limit of [the interviewees'] intentionality" close to what appears to be a breaking point. The fact that this material never "breaks" or fails to "mean" in spite of this radical rupture from its original context but rather "continues to work in successive contexts" (Butler 1997, p. 147) (potentially in ways that differ radically from the context of the interviewees' utterances), is precisely what problematizes the theatremakers' reworkings of the interviewees' words for their playscript. By detaching the interviewees' words from the context of their original utterances and re-inserting them into the playscript of My Country, the theatremakers of the play underline these words' "possibility of reinscription" (Butler 1997, p. 145). By highlighting this possibility, the play not only undermines verbatim theatre's privileging of the spoken utterance as a medium to access the truth of its interviewees' "lived experiences" but also highlights the potential of this theatre to represent the interviewees in ways they might never have envisaged, and perhaps more problematically, to represent the interviewees in ways that the original context of their utterance would have mitigated. However, I argue that My Country not only undermines verbatim theatre's privileging of the spoken utterance as a vehicle for truth by heightening the possible "disjuncture between utterance and meaning" (Butler 1997, p. 87) of the interviewees' words, but the play also exposes the theatremakers' assumption that the interviewees' "lived experiences" exist outside, what Derrida refers to as, an "interpretative [context]" (Derrida 1988a, p. 146).

\section{Lived Experience}

In an interview, Norris argued that he and his fellow NT theatre practitioners involved in the production of My Country attempted as far as possible to include only "opinions [that were] totally rooted in [the interviewees'] experiences one way or another", excluding "opinions [that were] rooted in something that they've picked up off Facebook news or The Daily News or The Guardian" (The National Theatre 2018a). In this way, Norris proffered the interviewees' "lived experience" as a guarantor for the system of semio-linguistic exchange at work in verbatim theatre, an impartial observer to offset what he regarded as the more untrustworthy "received" opinions formed from interviewees' encounters with news or social media. The "lived experiences" of the interviewees, therefore, became for Norris not simply a standard for evaluating the reality and truth of their lives and motivations for voting but the standard. Norris seems to imply that "lived experience" is already verified by virtue of being witnessed first-hand by the subject whereas what is read, heard, viewed on social and news media, by being conveyed through language, is therefore subject to the same linguistic vulnerability that afflicts all linguistic interactions-and for Norris, the implication is that its truth is, therefore, unverifiable.

Norris and Duffy's interpolation of the political voices throughout the play demonstrates the corrosion of public discourse that appears to have contributed to this devaluation (and consequent suspicion) of linguistic interaction. Like the regional voices of the interviewees, the words of the play's political figures are taken verbatim from "real" sources, albeit from public fora such as public speeches and TV interviews. Unlike the interviewees' voices, there is no suggestion that these political voices provide the audience of the play with access to a "truth" of these figures' experiences or even their sincere opinions. Indeed, the play arguably targets the insincerity of their words by selecting the most banal and most absurd soundbites delivered by these figures during the course of their campaigns. Cameron's slick managerial style is placed alongside Farage's and Johnson's "unvarnished" and 
apparently off-the-cuff remarks, the latter two figures' lack of nuance promoting itself as an absence of the mediation and spin deployed by Cameron. The play highlights (via Penny Layden's studied mimicry of Cameron, Farage, and Johnson) the performativity of these figures' various rhetorical strategies, that the "folksy" speeches of Farage "who tells it like it is", or the unmediated blunders of Johnson, might merely be different vehicles for the delivery of the same empty rhetoric of their predecessors. Ralph (from the South-West) encapsulates many of the other interviewees' mistrust of these political figures and their speeches when he comments that "[t]hey all talk absolute shit, frankly" (Duffy and Norris 2017, p. 32).

Although much public discourse during political campaigns is inevitably reduced to a tool for achieving political goals, the public's acceptance of this extreme instrumentalisation of political and social issues is perhaps more problematic. The almost complete transformation of political rhetoric into a tool for achieving specific ends at the cost of its communicative function that arguably occurs in many political campaigns (and certainly occurred during the EU Referendum debate) embodies this cynicism that both feeds off and signals a wider mistrust of political, economic, scientific and social institutions. Indeed, Jennifer Kavanagh and Michael D. Rich identify the "spinning [of] facts to the point of fiction" and its consequent "undermining [of] public confidence in institutions" by "[d]omestic political actors and governmental institutions" as one of the key factors in the recent surge of what they refer to as "truth decay" (Kavanagh and Rich 2018, p. xv). My Country's inclusion of Michael Gove's infamous comment, that "the people in [the UK] have had enough of experts" and should instead "trust themselves" (Duffy and Norris 2017, p. 31) promotes precisely the "blurring of the line between opinion and fact" that Kavanagh and Rich designate as one of the trends of this erosion of trust in public institutions (Kavanagh and Rich 2018, p. xv).

Ironically, Gove's comment also reflects the same privileging of "lived experience" as the chief arbiter of truth, as that expressed by Norris, dismissing all institutional knowledge as suspect regardless of the integrity of its source. Admittedly, the advice of experts (such as academics and economists) is often based on their interpretation of data that can sometimes appear esoteric to non-experts. Therefore, when expert opinion is challenged as biased or misleading, or when conflicting data is presented to counteract a claim, it can be extremely difficult for individuals to verify these data or attempt to determine the integrity of these expert opinions independently. In a context like the EU Referendum campaign period, where all claims (even those being made by respected and accountable sources) were being denounced as distorted by political biases, these expert interpretations of data become relegated to the status of subjective opinion rather than the result of rigorous research. At the same time, personal or "lived experiences" (that are already verified by being lived through and experienced by the individual voter) were elevated to the status of objective fact. The implication behind Gove's comment, therefore, is that knowledge acquired outside one's own personal "lived experiences" should be viewed with suspicion and even ignored because one can never possibly know or verify the trustworthiness of the information being communicated. During the campaign period for the EU Referendum, it was this faith in semio-linguistic interactions (whether these originated from trusted sources or not) that was arguably corroded by this cynicism (rather than scepticism) voiced by prominent campaigners, such as Gove.

While "expert opinion" is indeed often based on the interpretation of data rather than "lived experience", the more obvious derivation of knowledge from such "interpretive contexts" (such as that acquired through rigorous scientific investigation) does not necessarily invalidate it or de-hierarchize (or "de-sedimentize") established schools of thought-though importantly it does render them capable of being challenged. Indeed, Derrida stresses that "[w]hat is called 'objectivity', scientific for instance [... ] imposes itself only within a context which is extremely vast, old, powerfully established, stabilized or rooted in a network of conventions (for instance, those of language) and yet which still remains a context". As Derrida points out, "[t]hat does not in the slightest discredit them" (Derrida 1988a, p. 136). Gove's comment does not so much equivocate "expert opinion" and "lived experience" as invert their positions within the hierarchy of these "vast, old, powerfully established, 
stabilized [ ... ] conventions" and disregard the fact that "lived experience" itself also exists within these "interpretative contexts".

Norris' attempt to exclude everything except the interviewees' "lived experiences" from the play is arguably a symptom of this wider suspicion of language as a trustworthy channel for truth (as voiced by Gove) and the consequent paranoia of all communication that ensues from the sowing of such mistrust. Even if we set aside Derrida's assertion that "all reality has the structure of a differential trace" and that "one cannot refer to this 'real' except in an interpretive experience" (Derrida 1988a, p. 148), it is difficult to make the claim that the online social and news media platforms that Norris sought to exclude from the play have not become a large part of many individuals" "lived experience". Indeed, Mick Wallis and Patrick Duggan observe, that "experience is now, to varying degrees, wholly mediated" by these platforms (Duggan and Wallis 2011, p. 15). In a play attempting to delineate voters' reasons for choosing to remain or leave the EU, the desire to exclude such platforms, which have the potential to exert as much (if not more) influence on voters" behaviours as more tangible "real life" physical interactions, seems misguided. As has become clear in the aftermath of the EU Referendum, these online arenas have become some of the most important and contested spaces for campaign groups.

In fact, I would argue that in spite of Norris' desired exclusion of these "non-lived" influences from the playscript of My Country, the interviewees' responses actually force the audience to question whether the untangling of "lived experience" from these "interpretive contexts" is possible. The recirculation of social and news media discourses at various points in the verbatim material would suggest not. Eddie (South-West) and Desmond (Northern Ireland), all use the notorious myth proffered by Boris Johnson regarding the "crazy" EU regulations on bananas to express their disapproval of EU bureaucracy. Niamh (Northern Ireland) cites one encounter with dubious safety measures at a tourist site in Barcelona to make a sweeping generalisation about the work ethics of Greeks, Spaniards, and the French (Duffy and Norris 2017, p. 17). The comment made by Jonathan (Cymru) that immigrants are predominantly "murderers and rapists" echoes much of the extreme anti-immigration rhetoric in circulation during the campaign period and is almost certainly not based on his own "lived experiences" (Duffy and Norris 2017, p. 24).

Therefore, although Norris, like Gove, places the opinions derived from "lived experience" in opposition to those formed from solely engaging with a subject linguistically, the play actually suggests that in fact they are all operating on the same field of linguistic interaction. The recirculation of the opinions of political figures by the interviewees in My Country suggests that their lived experiences not only influence these discourses but are shaped by them also. Therefore, when the interviewee Donna argues that she no longer "feel[s] safe in the city as [she] used to" because of the rise in her region's immigrant population (Duffy and Norris 2017, p. 28), it is impossible to determine whether this opinion has been solely formed from her "lived experience" or whether her fear of the immigrant population has been fuelled by the anti-immigration rhetoric of Leave campaigners. From the selection of her words that are included in the playscript, it appears to be a combination of several factors-certainly her feelings of isolation in a community whose ethnic make-up has changed in a relatively short period of time, but also undoubtedly her own nativist beliefs that are perhaps fuelled by anti-immigration rhetoric.

In Stephen Coleman's examination of the "individual struggles of conscience that [underlie] preference formation" in electoral processes, he cites John S. Dryzek's "critique of the liberal 'image of a well-organised and unitary self' that knows what 'it' wants and needs" to demonstrate the "dramas of internal deliberation" that occur when such decisions are made. As Dryzek observes, "the political self is always a fractured entity" and

[e]ach voter is a site of competing internalised norms and scripts from which a silent vocabulary of moral reasoning is derived. Using this vocabulary to work through their experiences, feelings, and actions, voters must come to terms with the frequently inconsistent clusters of perceived interests and values that shape their political subjectivity [ ... ]. (Coleman 2013, p. 161) 
Dryzek's observation forces us to question the adequacy of the verbatim form in expressing what is perhaps an intrinsically "silent vocabulary". Coleman points out that while "interests and opinions fit comfortably within the conventional political lexicon", the feelings that give rise to them are "porous, moving fluidly between contexts that seem quotidian and non-political and situations that are manifestly politically charged but lack a language that can name or respond to the head or affect" (Coleman 2013, p. 146). In this sense, therefore, how does an interviewee express their inability to articulate their opinion on a subject or an experience if this inability or silence precludes their inclusion in the verbatim play?

While the verbatim technique allows Norris and Duffy to demonstrate the various social, political, and economic factors (migration, dissatisfaction with political leadership, economic hardship, as well as their views of the EU) that the interviewees claimed (or at least were willing to acknowledge) influenced their decisions to vote one way or another, the privilege ascribed by the verbatim form to interviewees' utterances has the effect of reducing these interviewees' motivations to what they said in response to these thematic parameters. As previously mentioned, for example, the speaker Donna features prominently in the section about immigration but less prominently elsewhere in the play. For the audience, therefore, Donna's identity is formed almost completely from the selected quotations of her opinions on this topic. Our reception of Donna is constructed as much by her absences as her presences in the play. As Dario Catiglione and Mark Warren observe, "what gets represented in democracies 'are not persons as such', but some of the interests, identities and values that persons have or hold" (Coleman 2013, p. 161). Rather than redress this necessary distillation that occurs when an individual participates in the electoral process (a distillation perhaps no more extreme than in a binary referendum), My Country arguably re-enacts this burden by "condensing [the interviewees'] multi-layered selves" down to their spoken utterances, words that "can never do justice to the plurality of their values" (Coleman 2013, p. 158).

\section{Conclusions}

During a post-show discussion for My Country, its producer Pádraig Cusack described the play as a "wake" for pre-Brexit Britain. However, Cusack struggled to articulate exactly what loss was being mourned by the play (The National Theatre 2018a). In this article, I have attempted to outline how the radical decontextualisation of the interviewees' voices in My Country coupled with the interventions of the theatremakers (via the play's highly-edited presentation of interviewees' voices) draws attention to these words' materiality and to the volatility of the value ascribed to them in the system of semio-linguistic exchange that defines verbatim theatre. Furthermore, the recirculation of the political voices by the interviewees in the playscript disrupts the notion that "lived experiences" can act as an external guarantor to this linguistic interaction. Consequently, I argue that My Country makes palpable in its highly-edited and decontextualized re-presentation of its verbatim material, the absence that lies at the heart of all linguistic exchange- "[ $t$ ]he absence of the sender or receiver" (Derrida 1988b, p. 49), the absence of a determinate meaning that marks the "limits of [their words'] intentionality" (Butler 1997, p. 10) and ensures their linguistic vulnerability, the absence that Derrida argues "belongs to the structure of all writing" and "all language in general" (Derrida 1988c, p. 5).

While it might be common to all language, My Country makes this absence uncomfortably conspicuous by investing the play's fractured voices with such an inflated value of truth in the playscript's repeated assertions of its origins in "real life". This inflation exposes the trust upon which much (if not all) linguistic interaction operates and reflects what could be regarded as the current crisis of faith in this system. Indeed, the widespread cynicism directed at public institutions and discourses, and the growing suspicion and paranoia of all linguistic interaction that have been witnessed during recent political events are arguably its symptoms. I would argue that this crisis, however, is not so much the result of this absence or the linguistic vulnerability that defines all speech but rather the seemingly wholesale exploitation of this vulnerability, the deployment of the "non-serious" or "oratio obliqua" (Derrida 1988c, p. 18) to which all speech is vulnerable; the "ironic, parasitical, metaphorical, 
citational, cryptic, fictional, literary, insincere" (Derrida 1988b, p. 72). During the EU Referendum campaign, public discourses became saturated with such speech. Perhaps the loss that My Country is "waking", therefore, is actually that "claim to veracity" not of its verbatim voices but of language itself, a loss that I would argue is reflected rather than (as Norris claims) redressed in My Country. In this climate of paranoia, where the word has seemingly become untethered from the "sedimentation of its usages [ ... ] that gives the name its force" (Butler 1997, p. 36), perhaps it is not so outlandish after all for the British Prime Minister to attempt to soothe the electorate's post-referendum anxieties with the (now infamous) reassurance that "Brexit means Brexit".

Funding: This research received no external funding.

Acknowledgments: This research was facilitated by The Dean's Grant for young academic staff at the Faculty of Education, Palacký University, Czech Republic.

Conflicts of Interest: The author declares no conflict of interest.

\section{References}

Austin, John Langshaw. 1975. How to Do Things with Words. Edited by James Opie Urmson and Marina Shisà. Cambridge: Harvard University Press.

Bottoms, Stephen. 2006. Putting the Document into Documentary: An unwelcome Corrective? TDR: The Drama Review 50: 56-68. [CrossRef]

Britain Stronger in Europe. 2016. Hundreds of Figures from Britain's Creative Industries Call for UK to Stay in the EU. Britain Stronger in Europe (Website). May 20. Available online: https:/ / www.strongerin.co.uk/hundreds_of_figures_from_britain_s_creative_industries_call_for_ uk_to_stay_in_the_eu\#EsfqoIC8Ax3v04FP.97 (accessed on 23 August 2018).

Butler, Judith. 1997. Excitable Speech: A Politics of the Performative. London: Routledge.

Cambridge Arts Theatre. 2017. My Country: 5 Minutes with National Theatre's Rufus Norris. Cambridge Arts Theatre (Website). May 19. Available online: https:/ / www.cambridgeartstheatre.com/news/my-country-5minutes-national-theatres-rufus-norris (accessed on 24 March 2018).

Clapp, Susannah. 2017. My Country: A Work in Progress review-A Laudable but Limp Look at Brexit Britain. The Observer (website). March 19. Available online: https:/ /www.theguardian.com/stage/2017/mar/19/ my-country-work-in-progress-dorfman-observer-review (accessed on 3 October 2018).

Claycomb, Ryan M. 2003. (Ch)oral History: Documentary Theatre, the Communal Subject and Progressive Politics. Journal of Dramatic Theory and Criticism 17: 95-122.

Coleman, Stephen. 2013. How Voters Feel. Cambridge: Cambridge University Press.

Derrida, Jacques. 1988a. Afterword: Toward an Ethic of Discussion, trans. Samuel Weber. In Limited Inc.. Evanston: Northwestern University Press.

Derrida, Jacques. 1988b. Limited Inc a b c .... Translated by Samuel Weber. In Limited Inc.. Evanston: Northwestern University Press.

Derrida, Jacques. 1988c. Limited Inc. Evanston: Northwestern University Press.

Derrida, Jacques. 2005. Writing and Difference. Translated by Alan Bass. London: Routledge.

Duffy, Carol Ann Duffy, and Rufus Norris. 2017. My Country; A Work in Progress. London: Faber and Faber.

Duggan, Patrick, and Mick Wallis. 2011. Trauma and Performance: Maps, narratives and folds. Performance Research 16: 4-17. [CrossRef]

Elmes, Simon. 2017. My Country: A Work in Progress. Seriously ... (Podcast), BBC Radio 4, March 9. Available online: https:/ / www.bbc.co.uk/programmes/b08h065b (accessed on 24 March 2018).

Federation: EU Referendum Response. 2016. Creative Industries Federation. June 8. Available online: https:/ /www. creativeindustriesfederation.com/news/federation-eu-referendum-response (accessed on 23 August 2018).

Gibson, Janet. 2011. Saying it right: Creating Ethical Verbatim Theatre. NEO: Journal for Higher Degree Research Students in the Social Sciences and Humanities 4: 1-18.

Hammond, Will, and Dan Steward. 2008. Verbatim Verbatim: Contemporary Documentary Theatre. London: Oberon.

Kavanagh, Jennifer, and Michael D. Rich. 2018. Truth Decay: An Initial Exploration of the Diminishing Role of Facts and Analysis in American Public Life. Santa Monica: Rand Corporation.

Martin, Carol. 2006. Bodies of Evidence. TDR/The Drama Review 50: 8-15. [CrossRef] 
McCorgray, Daisy. 2017. My Country: This Brexit Play Actually Listened to People in the UK. The New European (Website). March 3. Available online: https://www.theneweuropean.co.uk/culture/my-country-this-brexitplay-actually-listened-to-people-in-the-uk-1-4916207 (accessed on 24 March 2018).

Megson, Chris, and Alison Forsythe. 2009. Introduction. In Get Real: Documentary Theatre Past and Present. Edited by Chris Megson and Alison Forsythe. Hampshire: Palgrave Macmillan.

National Theatre Archives. 2017. Program for My Country; A Work in Progress. In Theatre Program Booklet. London: National Theatre Archives.

Sedgman, Sam, and Emma Reidy. 2017. Episode 1: Brexit. The National Theatre Podcast, The National Theatre. Available online: https:/ / www.nationaltheatre.org.uk/podcast (accessed on 3 October 2018).

Shipman, Tim. 2016. All Out War: The Full Story of How Brexit Sank Britain's Political Class. London: Harper Collins.

Stewart, Dixi. 2016. Front Row: The Cultural Response to Brexit. Front Row (Podcast), BBC Radio 4, July 26. Available online: https:/ / www.bbc.co.uk/programmes/b07m88y1 (accessed on 3 October 2018).

Stewart, Heather, and Mark Brown. 2016. Benedict Cumberbatch and Paloma Faith among 250 Stars Backing EU. The Guardian, May 20. Available online: https://www.theguardian.com/politics/2016/may/19/ british-cultural-heavyweights-sign-250-letter-backing-eu-benedict-cumberbatch-paloma-faith- (accessed on 3 October 2018).

Taylor, Lib. 2013. Voice, Body and the Transmission of the Real in Documentary Theatre. Contemporary Theatre Review 23: 368-79. [CrossRef]

The National Theatre. 2018a. My Country: Rufus Norris and Pádraig Cusack (Podcast). The National Theatre (Website). Available online: https:/ / www.nationaltheatre.org.uk/platform/podcast-mycountry (accessed on 3 October 2018).

The National Theatre. 2018b. My Country; A Work in Progress. The National Theatre (Website). Available online: https: / / www.nationaltheatre.org.uk/shows/my-country (accessed on 3 October 2018).

Warwick Arts Centre. 2017. My Country ... On Film. Youtube Video. April 24. Available online: https: / / www.youtube.com/watch?v=vOno44dCruU (accessed on 2 February 2019).

Young, Stuart. 2017. The Ethics of the Representation of the Real People and Their Stories in Verbatim Theatre. In Ethical Exchanges in Translation, Adaptation, and Dramaturgy. Edited by Emer O’Toole, Andrea Pelegrí Kristi and Stuart Young. Leiden: Brill Publishing.

(C) 2019 by the author. Licensee MDPI, Basel, Switzerland. This article is an open access article distributed under the terms and conditions of the Creative Commons Attribution (CC BY) license (http://creativecommons.org/licenses/by/4.0/). 